Красинский Владислав Вячеславович, кандидат юридических наук, член ОНМКС при ЦИК России

Источник опубликования: Красинский B.B. О коррупциогенных факторах избирательного законодательства // Российская юстиция. 2010. № 2. C. 22-24; www.krasinskiy.ru

\title{
О КОРРУПЦИОГЕННЫХ ФАКТОРАХ ИЗБИРАТЕЛЬНОГО ЗАКОНОДАТЕЛЬСТВА
}

В своем Послании Федеральному Собранию Российской Федерации от 12 ноября 2009 г. Президент Российской Федерации назвал коррупцию одним из главных барьеров на пути развития России. Глава государства подчеркнул, что борьба с коррупцией «должна вестись по всем направлениям: от совершенствования законодательства, работы правоохранительной и судебной систем - до воспитания в гражданах нетерпимости к любым, в том числе бытовым, проявлениям этого социального зла» ${ }^{1}$. Потребности совершенствования законодательства в контексте противодействия коррупции существуют в большинстве отраслей. Не является исключением и избирательное законодательство. Законодательные акты о выборах, как и другие нормативные регуляторы российской правовой системы, нуждаются в коррупциогенной экспертизе, что обусловливает актуальность изучения коррупциогенных факторов избирательного законодательства ${ }^{2}$.

Несмотря на развитие демократических институтов Российской Федерации и модернизацию нормативной правовой базы, связанной с выборами, в законодательстве, регулирующем организацию и проведение выборов в Российской Федерации, на сегодняшний день не полностью ликвидированы пробелы и коллизии, часть из которых носит коррупциогенный характер. Формулировки частей 7-10 статьи 91 Федерального закона «О выборах депутатов Государственной Думы Федерального Собрания Российской Федерации», связанные с возможностью отмены решения Центральной избирательной комиссии 
Российской Федерации о регистрации списка кандидатов, об отказе в его регистрации, об исключении группы кандидатов из списка кандидатов, с отменой регистрации федерального списка кандидатов, отменой регистрации кандидатов, включенных в зарегистрированный федеральный список кандидатов, с исключением региональной группы кандидатов из федерального списка, допускают возможность выборочного правоприменения и нарушения равного статуса субъектов избирательного процесса. На федеральном уровне отсутствуют правовые нормы, препятствующие конъюнктурному изменению законодательства о выборах; вне периода избирательной кампании не регулируются отношения, связанные с политической рекламой; не предусмотрена юридическая ответственность иностранных (международных) наблюдателей за нарушение общепризнанных международных принципов и норм наблюдения за выборами.

Коррупциогенные факторы, противоречия и несоответствие правовых положений нормам федерального законодательства присутствуют в уставах и законодательных актов значительной части субъектов Российской Федерации ${ }^{3}$. Так, ст. 31 Устава Ярославской области от 23 мая 1995 г. (в ред. от 25 февраля 2009 г.) допускает возможность избираться лицам, осужденным к лишению свободы за совершение тяжких и (или) особо тяжких преступлений и имеющим на день голосования на выборах неснятую и непогашенную судимость за указанные преступления; осужденным за совершение преступлений экстремистской направленности, предусмотренных Уголовным кодексом Российской Федерации, и имеющим на день голосования на выборах неснятую и непогашенную судимость за указанные преступления; подвергнутым административному наказанию за совершение административного правонарушения, предусмотренного статьей 20.3 Кодекса Российской Федерации об административных правонарушениях, если голосование на выборах состоится до окончания срока, в течение которого лицо считается подвергнутым административному наказанию. 
Аналогичные пробелы имеют Закон Республики Тыва от 23 июня 2006 г. (в ред. от 25 июля 2007 г.) № 1867 ВХ-1 «О выборах депутатов Палаты представителей Великого Хурала Республики Тыва», законы Тульской области от 8 июля 2008 г. № 1055-3ТО «О регулировании отдельных правоотношений, связанных с выборами депутатов представительных органов муниципальных образований, членов иных выборных органов местного самоуправления», от 18 июля 2008 г. № 1066ЗТО «О регулировании отдельных правоотношений, связанных с выборами главы муниципального образования, иного выборного должностного лица местного самоуправления», от 19 декабря 2008 г. (в ред. от 3 июня 2009 г.) № 1198-3ТО «О регулировании отдельных правоотношений, связанных с выборами депутатов Тульской областной Думы», Закон Еврейской автономной области от 29 марта 2006 г. (в ред. от 31 мая 2006 г.) № 662-О3 «О выборах депутатов Законодательного Собрания Еврейской автономной области».

Распространенным недостатком законов субъектов Российской Федерации о выборах является неурегулированность ряда избирательных действий, что ведет к правовой неопределенности. В настоящее время в законах Республики Тыва от 23 июня 2006 г. (в ред. от 25 июля 2007 г.) «О выборах депутатов Палаты Представителей Великого Хурала Республики Тыва» и Республики Коми от 7 июля 2006 г. (в ред. от 17 апреля 2009 г.) «О выборах, референдумах и опросе в Республике Коми» недостаточно регламентируются вопросы открытия избирательных счетов кандидатов.

В упомянутом Законе Республики Коми, законах Тульской области от 8 июля 2008 г. № 1055-3ТО «О регулировании отдельных правоотношений, связанных с выборами депутатов представительных органов муниципальных образований, членов иных выборных органов местного самоуправления», от 18 июля 2008 г. № 1066-3ТО «О регулировании отдельных правоотношений, связанных с выборами главы муниципального образования, иного выборного должностного лица 
местного самоуправления», от 19 декабря 2008 г. (в ред. от 3 июня 2009 г.) № 1198-3ТО «О регулировании отдельных правоотношений, связанных с выборами депутатов Тульской областной Думы» отсутствуют ограничения на предвыборную агитацию на предмет недопущения экстремизма.

Закон Ставропольского края от 8 февраля 2006 г. № 6-К3 «О некоторых вопросах проведения выборов в органы местного самоуправления», Закон Волгоградской области от 25 октября 2008 г. № 1751-ОД «О выборах депутатов Волгоградской областной Думы», Закон Республики Коми от 7 июля 2006 г. (в ред. от 17 апреля 2009 г.) № 65-Р3 «О выборах, референдумах и опросе в Республике Коми», законы Тульской области от 8 июля 2008 г. № 1055-3ТО «О регулировании отдельных правоотношений, связанных с выборами депутатов представительных органов муниципальных образований, членов иных выборных органов местного самоуправления», от 18 июля 2008 г. № 1066ЗТО «О регулировании отдельных правоотношений, связанных с выборами главы муниципального образования, иного выборного должностного лица местного самоуправления», от 19 декабря 2008 г. (в ред. от 3 июня 2009 г.) № 1198-3ТО «О регулировании отдельных правоотношений, связанных с выборами депутатов Тульской областной Думы» не содержат никаких положений о контрольно-ревизионных службах при избирательных комиссиях.

Закон Брянской области от 23 января 2008 г. (с изм. от 11 ноября 2008 г.) № 4-3 «О выборах депутатов Брянской областной Думы» не регулирует порядок использования ГАС «Выборы». Аналогичные правовые положения отсутствуют в законах Тульской области от 8 июля 2008 г. № 1055-3ТО «О регулировании отдельных правоотношений, связанных с выборами депутатов представительных органов муниципальных образований, членов иных выборных органов местного самоуправления», от 18 июля 2008 г. № 1066-3ТО «О регулировании отдельных правоотношений, связанных с выборами главы муниципального 
образования, иного выборного должностного лица местного самоуправления», от 19 декабря 2008 г. (в ред. от 3 июня 2009 г.) № 1198 ЗТО «О регулировании отдельных правоотношений, связанных с выборами депутатов Тульской областной Думы», Законе Ставропольского края от 8 февраля 2006 г. № 6-К3 «О некоторых вопросах проведения выборов в органы местного самоуправления», а также в Законе Республики Коми от 7 июля 2006 г. (в ред. от 17 апреля 2009 г.) «О выборах, референдумах и опросе в Республике Коми».

В законодательстве ряда субъектов Российской Федерации (Республика Ингушетия, Чеченская Республика, Ивановская область, Кемеровская область, Костромская область, Тамбовская область) закреплено коррупциогенное положение о том, что если кандидат без вынуждающих к тому обстоятельств не сложил с себя полномочия, несовместимые со статусом депутата, выборного должностного лица, в результате чего назначены повторные выборы, этот кандидат должен полностью или частично возместить соответствующей избирательной комиссии произведенные ею расходы, связанные с проведением повторных выборов. Таким образом, объем возмещения расходов на проведение повторных выборов зависит от усмотрения избирательной комиссии. В целях устранения возможности выборочного правоприменения из статьи 81 Закона Республики Ингушетия от 28 мая 2009 г. № 24-Р3 «О муниципальных выборах в Республике Ингушетия», статьи 83 Закона Чеченской Республики от 10 мая 2007 г. (в ред. от 21 июля 2009 г.) № 32-Р3 «О муниципальных выборах в Чеченской Республике», пункта 10 статьи 56 Закона Ивановской области от 27 июня 2003 г. (в ред. от 17 июня 2008 г.) № 60-О3 «О выборах», части 3 статьи 61 Закона Кемеровской области от 12 декабря 2005 г. (в ред. от 8 апреля 2009 г.) № 147-О3 «О выборах в органы местного самоуправления Кемеровской области», статьи 145 Избирательного кодекса Костромской области от 30 декабря 1998 г. (в ред. от 6 июля 2009 г.) № 39-ЗКО, части 3 статьи 84 
Закона Тамбовской области от 31 января 2007 г. (в ред. от 1 июля 2009 г.) № 146-3 «О выборах депутатов представительных органов муниципальных образований в Тамбовской области» предлагается исключить словосочетание «или частично».

В связи с этим требуется дальнейшее развитие законодательного обеспечения избирательного процесса в направлении противодействия коррупции. Устранение коррупциогенных факторов избирательного законодательства позволит повысить уровень доверия населения к представительным органам власти, снизит социальную напряженность в обществе, будет способствовать демократизации и укреплению законности избирательного процесса.

\section{Аннотации:}

В статье анализируется проблема коррупционности избирательного законодательства. Автором рассмотрены федеральные и региональные законы о выборах, изучены коррупциогенные нормы законов о выборах.

Ключевые слова: коррупция в избирательном процессе, правовое регулирование выборов, коррупциогенные нормы, федеральные законы о выборах, региональные законы о выборах.

Key words: electoral corruption, legal regulation of elections.

${ }^{1}$ См. Рос. газ. 2009. 13 ноября.

${ }^{2}$ См.: Бородин С.В., Лунеев В.В. О криминологической экспертизе законов и иных нормативных актов // Государство и право. 2002. № 6. С. 41; Постников А.E. Избирательное законодательство: необходимо четкое разделение полномочий между различными уровнями власти при проведении выборов // Журнал российского права. 2002. № 5. С. 21-22; Кабанов П.А., Райков Г.И., Чирков Д.К. Политическая коррупция в условиях реформирования российской государственности на рубеже веков: Монография. М.: Дружба народов, 2008. С. 107; Мальщев Г.В., Носов С.И. Коррупциогенные факторы в юридических нормах: природа, формы проявления, проблемы устранения // Право и образование. 2009. № 1. С. 4-12.

3 См.: Красинский В.В. Правовое обеспечение избирательного процесса в интересах национальной безопасности России. Монография. Тамбов, 2009. С. 90-91; 308-310. 